\title{
FTIR spectroscopic study of palygorskite: Influence of the composition of the octahedral sheet
}

\author{
M. Suárez ${ }^{\mathrm{a}, *}$, E. García-Romero ${ }^{\mathrm{b}}$ \\ ${ }^{a}$ Dpto. de Geología, Área de Cristalografia y Mineralogía, Universidad de Salamanca, Plaza de la Merced s/n E-37008 Salamanca, Spain \\ ${ }^{\mathrm{b}}$ Dpto. de Cristalografia y Mineralogía, Facultad de C. C. Geológicas, Universidad Complutense, E-28040 Madrid, Spain
}

\begin{abstract}
The influence of chemical composition to position and intensity of the absorption bands observed in the FTIR spectra of palygorskite has been studied by a detailed comparative study of six samples. Palygorskites studied have high purity and different chemical composition. At one extreme, there are two samples that correspond to Mg-rich palygorskites, at the other extreme a sample with a composition very close to the theoretical formula of this mineral, and there are three further samples whose structural formulae lie between these extremes. The position of the bands identified in the FTIR spectra of the palygorskites studied is similar for all samples, but there are some differences in their intensity, which are significant. Analysing these intensities, valuable information about the distribution of cations along the octahedral sheet has been obtained. Isomorphic substitution in octahedral sheet occurs only in M2 position. Al, and Fe may occupy M2 position whereas Mg can occupy all possible sites: M1, M2 and M3.
\end{abstract}

Keywords: Palygorskite; FTIR spectroscopy; Structural formulae; Octahedral sheet

\section{Introduction}

Palygorskite is a clay mineral with a wide variety of industrial applications. This mineral has some particularly desirable sorptive, colloidal-rheological, and catalytic properties, in comparison with other clay minerals (Jones and Galán, 1988). Technological applications are based on its physicochemical properties, principally on composition, surface area, porosity, among others, and especially in its fibrous structure. Bradley (1940) described the structure of palygorskite, then referred to as attapulgite, a term now used in mining terminology. It is a 2:1 phyllosilicate in which the sheets of silica tetra-

\footnotetext{
* Corresponding author.

E-mail address: msuarez@usal.es (M. Suárez).
}

hedra are periodically inverted with respect to the tetrahedral bases. As a result of this inversion, the octahedral sheets are periodically interrupted and terminal cations must complete their coordination sphere with water molecules. As only four of five octahedral positions available (as an average) are filled, palygorskite appears to be intermediate between dioctahedral and trioctahedral minerals (Martín Vivaldi and Fenoll, 1970). When compared to others phyllosilicates, even to sepiolite, palygorskite is very different because it does not have an "actual octahedral sheet", the octahedral ribbon is very sharp, more similar to a chain, and there are three different types of water molecules.

Considering the structure of palygorskite, there are several bonds that can give absorption effects in IR region. As in other clay minerals, the most intense absorptions are related to water and hydroxyl stretching 
and bending vibratiens. This mineral has three types $\bullet$ water in its structure (Fig. 1), the first of which, named

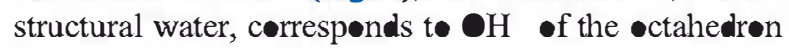
place in the central positions $\bullet$ the $\bullet$ ctahedral sheet. In the theoretical model (with $\mathrm{Mg} / \mathrm{Al}=1$ and four ectahedral positions eccupied) $2 \mathrm{M} 2-\mathrm{OH}$ bonds are present because the central $\bullet$ ctahedrøn is vacant, as correspønds to a diectahedral model (Fig. 1). But in a triectahedral model, which $\mathrm{Ml}$ pesition is eccupied, $\mathrm{M} 1-2 \mathrm{M} 2-\mathrm{OH}$ bønds alse eccur. The cations that $\bullet$ ccupy the mest

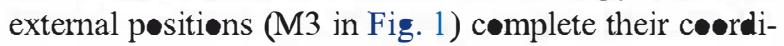

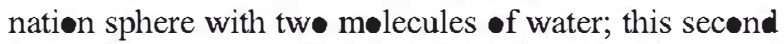
type of water is named coordinated water or bonded water, as mentioned above. The last type is named zelitic water, which is found inside the palygorskite channels.

Güven et al. (1992), for a diectahedral palygerskite with a theoretical formula $\mathrm{Si}_{8} \mathbf{O}_{2} \cdot\left(\mathrm{Al}_{2} \mathrm{Mg}_{2}\right)(\mathbf{O H})_{4}$ $\left(\mathrm{OH}_{2}\right)_{4} \cdot 4 \mathrm{H}_{2} \mathbf{O}$, proposed that $\mathrm{Al}$ eccupies the $\mathrm{M} 2$
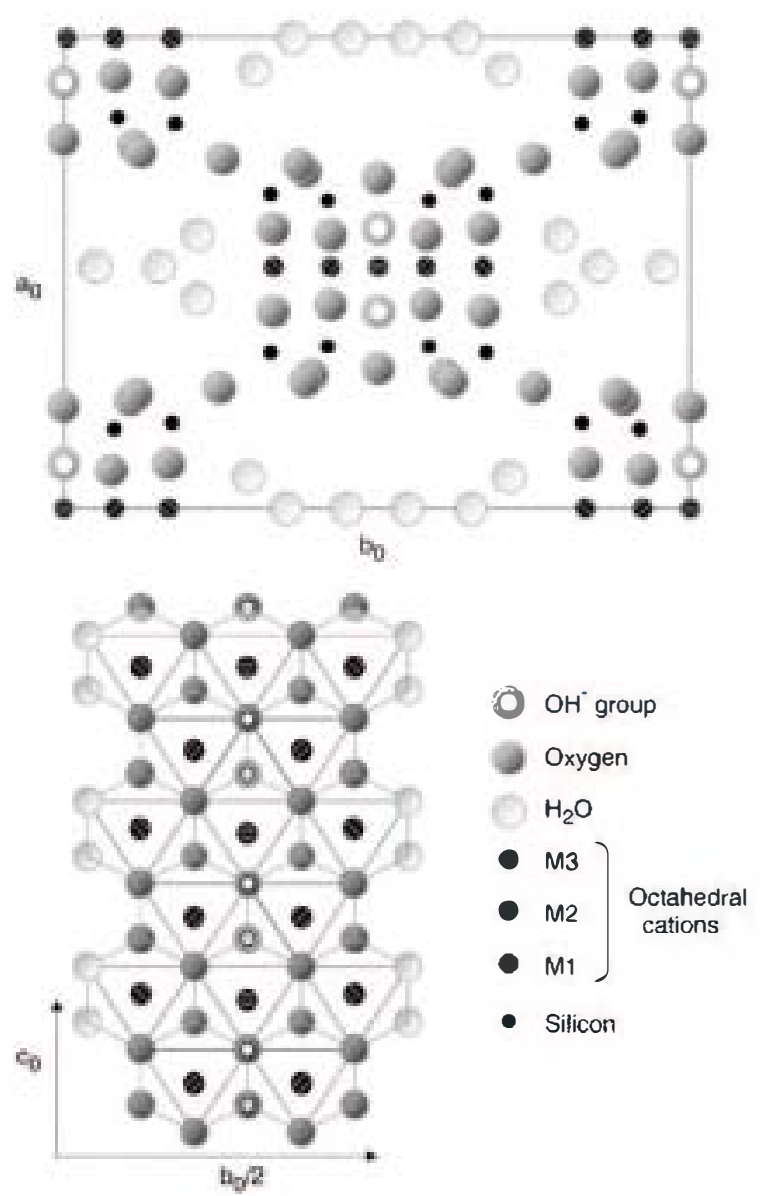

Fig. 1. Stuctural scheme of palygorskite projected on (101) according to Bradley (1940), and octahedral ribbon according to Güven et al. (1992). pesition, $\mathrm{Mg}$ the M3 and M1 is vacant (Fig. 1). Considering this structural formula, $\mathbf{M g}-\mathrm{OH}_{2}$ and $\mathrm{Al}-$ $\mathrm{Al}-\mathrm{H}$ bonds are present, and their correspending abserptions may be found in the spectra. But in all palygerskites there can be certain differences between this ideal formula and their actual compesition. The $\mathrm{Mg} /$ Al ratio is higher than 1, the number of ectahedral pesitions $\bullet c c u p i e$ can be greater than 4 , and substitution of $\bullet$ ctahedral $\mathrm{Al}$ by $\mathrm{Fe}^{3+}$ is present in all palygorskites (García-Romer et al., 2004).

These differences between the theretical and actual compesition must be taken int account when the FT R spectra are interpreted. If the number of octahedral positions occupied is greater than 4, then M1 may be partially $\bullet$ ccupied and it is possible to find a new type $\bullet$ bond (triectahedral model): M1-2M2-OH. In this case the three cations, $\mathrm{Al}, \mathrm{Mg}$ and Fe, wøuld $\bullet c c u p y$ the $\mathrm{Ml}$ position, depending $\bullet n$ the compesition of the sample. Alsø, the number of $\bullet$ ctahedral catiøns can be greater than 4 and this is $\bullet$ nly possible with more than $2 \mathrm{R}^{2+}$ cations ( $\mathrm{Mg}$ in palygerskite) in order to have a charge of 10 per half-cell, and then the most probable bonds are $3 \mathrm{Mg}-\mathrm{OH}$ or $(\mathrm{Al}, \mathrm{Fe})-2 \mathrm{Mg}-\mathrm{OH}$.

In addition to these considerations, the modification of the spectra after heating, and the consequent dehydration of the palygorskite, is very helpful for a correct interpretation. Løss of both zeølitic and ceordinated water molecules after heating, as it can be seen by thermal techniques such as DTA and TGA, •ccurs in a reversible precess up to $350^{\circ} \mathrm{C}$ (Hayashi et al., 1969; Singer, 1989; Cases et al., 1991 and Khorami and Lemieux, 1989, amøng others). Abøve $35{ }^{\circ} \mathrm{C}$, hemihydrated palygerskite is formed and the process is irreversible. After heating below $35{ }^{\circ} \mathrm{C}$, the $\mathrm{M} 3-\mathrm{OH}_{2}$ bonds are modified whereas the $2 \mathrm{M} 2-\mathrm{OH}$ bonds remain unmedified.

Most studies on FTR of palygorskites interpret the abserptions $\bullet$ bserved in spectra either according to the theoretical formula, or either according to the formula -btained from bulk analyses of raw sample, which may contain some impurities. Taking int account that there is certain variability in the structural formulae of palygorskite, the aim of this work is to study how chemical compesition influences the position and intensity of the vibrations in the FTR spectra. Therefore, an FTR spectroscopy study has been carried -ut, on several palygorskites, which have a wellknown chemical compesition, and the absorptions -bserved in the spectra have been related to structural formulae. By this means, valuable information abøut the distribution of cations aleng the ectahedral sheet can be ebtained. 


\section{Experimental}

\subsection{Materials}

The following six palygorskites selected for their high purity have been used in this work, the first three collected by the authors:

(1) ESQ sample proceeds from Esquivias, Toledo (Spain). Characterized by García-Romero et al. (2004).

(2) LIS palygorskite proceeds from Volcanic Complex from Lisbom (Portugal)

(3) TRA palygorskite proceeds from Cabo de Gata, Almería (Spain)

(4) Palygorskite from Florida, (USA) supplied by Source Clays as PF1-1 and referred to as ATT in this work. This palygorskite has been widely reported in literature and has been used as a reference sample in numerous works including the "Baseline studies of the Clay Minerals Society Source Clays" (Costazo and Guggenheim, 2001).

(5) TOR palygorskite was supplied by TOLSA Company and comes from the ore of Torrejón el Rubio, Cáceres (Spain). It was studied by Galán et al. (1973) and Fernández Macarro and Blanco Sánchez (1990).

(6) YUC palygorskite from Ticul, Yucatán (Mexico), supplied by Mr. Manuel Sanchez del Rio, was reported by Isphording (1984).

These palygorskites have been selected not only for their high purity but also for their different chemical composition. At one exreme, there are two samples that correspond to $\mathrm{Mg}$ rich palygorskites: ESQ and TRA. At the other exweme, LIS sample has a composition very close to theoretic formula of this mineral, and there are three further samples whose structural formulae are between these extremes (ATT, TOR and YUC).

\subsection{Techniques}

Chemical composition was obtained by analytical electron microscopy (AEM) of isolated particles with transmission electron microscopy (TEM), in samples of great purity using a JE 2000 FX microscope equipped with a double-tilt sample holder (up to a maximurn of $\pm 45^{\circ}$ ) at an acceleration voltage of $200 \mathrm{kV}$, with $0.5 \mathrm{~mm}$ zeta-axis displacement and $0.31 \mathrm{~nm}$ point-to-point resolution. The microscope incorporates an OXFORD ISIS energy dispersive X-ray spectrometer $(136 \mathrm{eV}$ resolution at $5.39 \mathrm{keV})$ and has its own software for quantitative analysis. Structural formulae of palyorskites were calculated on the basis of 21 oxygens per unit cell. All the $\mathrm{Fe}$ present was considered as $\mathrm{Fe}^{3+}$ (owing to the limitation of the teclnique), but the possible existence of $\mathrm{Fe}^{2+}$ should be taken into account.

Mineralogical characterization was performed by X-ray diffraction (XRD) using a Siemens 500 XR diffractometer with $\mathrm{Cu} \mathrm{K} \alpha$ radiation and a graphite monochromator. The samples used were random-powder specimens. Powders were scanned from $2^{\circ}$ to $65^{\circ} 2 \boldsymbol{\theta}$ at a $\boldsymbol{0 . 0 2 ^ { \circ }} 2 \boldsymbol{\theta} / 3 \mathrm{~s}$ scan speed.

The Fourier ransformed infrared spectrome (FTR) was recorded in the 4000 to $400 \mathrm{~cm}^{-1}$ range on a BRUKER EQUINOX 55 spectrometer. The samples were prepared using the $\mathrm{KBr}$ pellet teclnique. All samples were studied under the same hydration conditions, kept over $\mathrm{H}_{2} \mathrm{~S}_{4}$ solutions ( $\mathrm{R} . \mathrm{H} .=45 \%$ ). The mixtures of the clays, and dried $\mathrm{KBr}$ (ratio 1:200) were subjected to a pressure of 8 ton $\mathrm{cm}^{-2}$.

The statistic reament of data was carried out using the SPSS 10.0 program.

\section{Results and discussion}

\subsection{X-ray diffraction}

Fig. 2 shows the X-ray diffractegrams of the whele sample of the palygorskites studied. The high purity

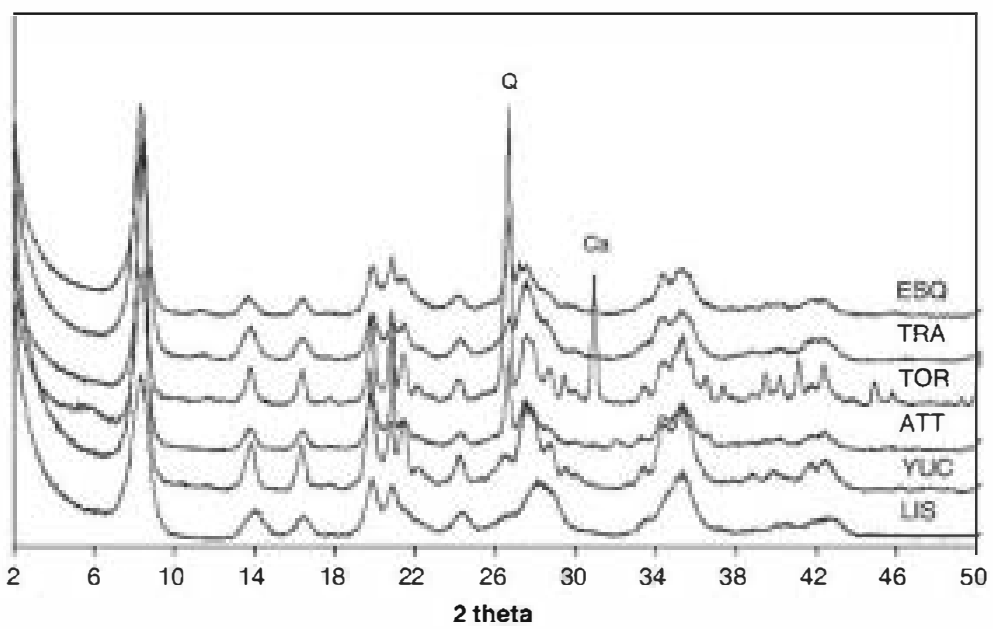

Fig. 2. XRD pattems of whole sample of the palygorskites studied. Q: quartz and Ca: calcite 
Table 1

Structural formulae for the six palygorskites studied, obtained from AEM analyses of isolated particles on the basis of 21 oxygen atoms

\begin{tabular}{|c|c|c|c|c|c|c|c|c|}
\hline Sample & $\mathrm{Si}$ & $\mathrm{AI}^{\mathrm{IV}}$ & $\mathrm{AI}^{\mathrm{VI}}$ & $\mathrm{Fe}^{3+}$ & $\mathrm{Mg}$ & ¿Oct. C. & $\mathbf{R}^{3+}$ & $\mathbf{R}^{3+} \mathbf{R}^{2+}$ \\
\hline ESQ & 7.87 & $\bullet .13$ & 1.04 & 0.20 & 3.11 & 4.35 & 1.24 & - .4 \\
\hline TRA & 8.02 & - & 1.2 & $\bullet .16$ & 2.89 & 4.25 & 1.36 & - .47 \\
\hline TOR & 7.91 & 0.09 & 1.48 & 0.37 & 2.25 & 4.10 & 1.85 & 0.82 \\
\hline ATT & 7.85 & $\bullet .15$ & 1.47 & 0.25 & 2.30 & 4.02 & 1.72 & $\bullet .75$ \\
\hline YUC & 7.85 & $\bullet .15$ & 1.57 & 0.24 & 2.21 & 4.02 & 1.81 & 0.82 \\
\hline LIS & 8.02 & - & 1.91 & 0.04 & 2.11 & 3.96 & 1.95 & 0.97 \\
\hline
\end{tabular}

-f the samples has been confirmed from the diffractograms. Only small amounts of quartz in the ATT and the ESQ sample and calcite in the TOR sample have been found. The high crystallinity of the YUC and TOR samples can be deduced from the higher narrewness of the principal peaks. It is very impertant to take int account the purity of each sample, given that the impurities have their ewn abserption features. It must be pointed that in all the samples studied, except the very small amounts of smectite in

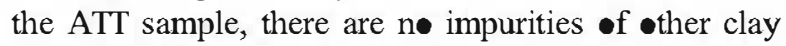
minerals, which have some abserption features similar to palygorskite.

\subsection{Chemical composition}

Table 1 shows the average structural formulae for the six palygerskites studied, the data were $\bullet$ btained from AEM analyses of is late particles. It can be -bserved that there are some significant differences. The Al that occupies tetrahedral positions ranges between $\mathbf{0 . 1 5}$ (for the ESQ and YUC samples) and 0 (for the LIS and TRA samples). The most impertant differences were found in the ectahedral cations content. Al, $\mathrm{Mg}$ and $\mathrm{Fe}$ are present in all the palygorskites studied, but the rativ among them strongly varies among the different samples. At one extreme there is an $\mathrm{R}^{3+} / \mathrm{R}^{2+}$ ratio close to 1 without $\mathrm{Fe}^{3+}$ for the LIS sample, as corresponds to theoretical palygorskite, at the other there is a rati $\mathrm{R}^{3+} / \mathrm{R}^{2+}=0.4$ for the ESQ sample, the most $\mathrm{Mg}$-rich palygorskite. $\mathrm{Fe}^{3+}$ content varies between 0.04 (LIS) and 0.37 (TOR) and it is very similar to the other samples studied, approximately $\mathbf{0 . 2}$ cations per half-cell.

Therefore, the samples studied range between an Alrich palygorskite and a very $\mathrm{Mg}$-rich palygorskite and with respect to $\mathrm{Al} / \mathrm{Mg}$ content they can be ordered thus: LIS-YUC-TOR-ATT-TRA-ESQ.
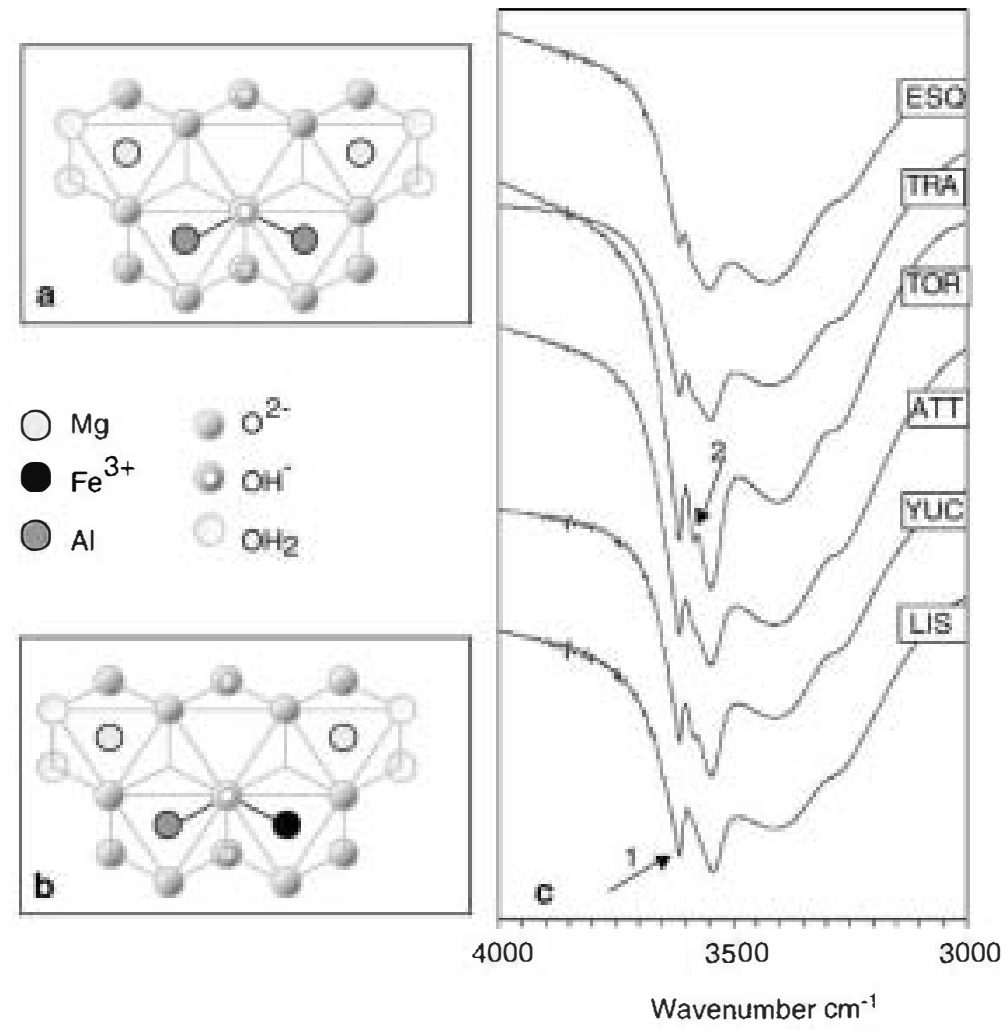

Fig. 3. Suctural scheme of octahedral sheet for a half-cell of palygorskite showing different

(c) FTIR spectra in the region of high wavenumber of the palygorskites studied. 


\subsection{FTIR spectroscopy}

The pesition of the bands identified in the FTR spectra of the palygorskites studied is similar for all samples because all of them are very pure palygorskites, but there are some differences in their intensity, which are significant. The presence of small quantities - impurities can easily be detected in the FTR spectra. Calcite is detected in the TOR sample by its characteristic band at $1430 \mathrm{~cm}^{1}$ and a shoulder at $876 \mathrm{~cm}^{1}$ (typical frøm carbønate aniøns) while quartz preduces bands at 798 and $778 \mathrm{~cm}^{1}$ in the ATT sample.

The spectra can be divided int twe regiens in order to make easier their study, the $\mathbf{O H}$-stretching vibration region and the water bending vibration.

\subsubsection{OH-stretching vibration region}

In the higher wavenumber region of the samples studied the following can be observed (Fig. 3):

(1) A sharp peak at $3616 \mathrm{~cm}^{1}$.

(2) A peak $\bullet$ shøulder at $3580 \mathrm{~cm}{ }^{1}$, which appears only in some samples.

(3) Three bands centred at 3550,3400 and $3350 \mathrm{~cm}^{1}$.

The first effect, at $3616 \mathrm{~cm}^{1}$, is described in all bibliøgraphic references on FTR of palygorskite (Mendeløvici, 1973; Prøst, 1973; Blanc॰ et al., 1988; Frøst et al., 1998, 2001; Shuali et al., 1987; McKeown et al., 2002; Chahi et al., 2002, amøng others) and it seems to be characteristic of this mineral. Frøm heating and deuteration Mendelevici (॰p. cit.) concluded that this peak must be adscribed to bonds located in "inaccessible pesitions" in palygerskite, and therefore must be related to $2 \mathrm{M} 2-\mathrm{OH}$ bonds. It is well established in the literature that this is due to the $\mathrm{OH}$-stretching mode in $\mathrm{Al}_{2}-$ $\mathrm{OH}$ groups (Fig. 3a). This band has been found in all the samples here studied, but with different intensities. In Fig. 3c, it will be noted that the highest intensities for this peak (labelled as 1) correspond to the LIS and TOR samples, and the lowest to the ESQ and TRA samples. As it is not possible to measure the area of the peak, the difference of transmittance between 3602 and 3616 $\mathrm{cm}^{1}$ for each sample was measured with the aim of

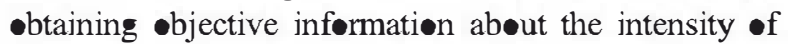
this peak. The existence of a possible correlation between the ectahedral content and the intensity of the peak $\left(I_{3616 \mathrm{~cm}}{ }^{1}\right.$ in Table 2$)$ has been investigated. The correspending matrix of correlation is sh॰wn in Table 2. As can be seen, the peak 0 $3616 \mathrm{~cm}^{1}$ is related with the content $\bullet \mathrm{R}^{3+}$ and not $\bullet$ nly with the $\mathrm{Al}$, that is to say, with the diectahedral character of the mineral. While the coefficient of correlation (Pearson's correlation) for $\mathrm{Al}$ is $\mathbf{0 . 9 2 2}$, the $\mathrm{R}^{3+} / \mathrm{R}^{2+}$ presents a higher correlation: 0.982 . Therefore, the intensity of this peak indicates the highest diectahedral character of the palygorskite, which is clearly related to the highest $\mathrm{Al}$ ectahedral content and to the lowest $\mathrm{Mg}$ content (-0.990). A peak at similar wavenumber, als• related to $\mathrm{Al}-\mathrm{Al}-\mathrm{OH}$ stretching vibratien, can alse be found in -ther diectahedral and aluminic clay minerals such as

Table 2

Correlation matrix of crystallochemical data and peak intensities in the FTIR spectra

\begin{tabular}{|c|c|c|c|c|c|c|c|c|c|c|}
\hline & & $\mathrm{Al}$ & $\mathrm{Mg}$ & $\mathrm{Fe}$ & Oct. Cat. & $\mathbf{R}^{3+}$ & $\mathbf{R}^{3+} \mathbf{R}^{2+}$ & $I_{3616 \mathrm{~m}>1}$ & $I_{912 \mathrm{~m}}{ }^{1}$ & $I_{510} \mathrm{~m}^{1}$ \\
\hline \multirow[t]{2}{*}{$\mathrm{Al}$} & C.C. & 1.000 & -0.945 & -0.317 & $-\bullet .935$ & 0.933 & 0.963 & 0.922 & 0.918 & 0.924 \\
\hline & B.S. & & 0.004 & 0.54 & $\bullet .006$ & 0.007 & 0.002 & 0.009 & 0.010 & 0.008 \\
\hline \multirow[t]{2}{*}{$\mathrm{Mg}$} & C.C. & -0.945 & 1.000 & 0.004 & 0.977 & -0.994 & -0.992 & -0.990 & -0.744 & -0.797 \\
\hline & B.S. & $\mathbf{0 . 0 0 4}$ & & 0.994 & $\bullet .001$ & 0.000 & 0.000 & 0.000 & 0.090 & 0.058 \\
\hline \multirow[t]{2}{*}{$\mathrm{Fe}$} & C.C. & -.317 & 0.004 & 1.000 & 0.099 & 0.046 & -054 & 0.03 & -.647 & -0.490 \\
\hline & B.S. & 0.54 & 0.994 & & 0.852 & 0.931 & 0.918 & 0.955 & 0.165 & 0.324 \\
\hline \multirow[t]{2}{*}{ Oct. Cat. } & C.C. & $-\bullet .935$ & 0.977 & 0.099 & 1.000 & -0.947 & -0.955 & -0.971 & -0.759 & -0.787 \\
\hline & B.S. & 0.006 & 0.001 & 0.852 & & 0.004 & 0.003 & 0.001 & 0.080 & 0.063 \\
\hline \multirow[t]{2}{*}{$\mathbf{R}^{3+}$} & C.C. & 0.933 & -0.994 & 0.046 & -0.947 & 1.000 & 0.994 & 0.982 & 0.722 & 0.788 \\
\hline & B.S. & 0.007 & 0.000 & 0.931 & 0.004 & & 0.000 & 0.000 & 0.105 & 0.063 \\
\hline \multirow[t]{2}{*}{$\mathbf{R}^{3+} \mathbf{R}^{2+}$} & C.C. & 0.963 & -0.992 & $-\mathbf{0 . 0 5 4}$ & -0.955 & 0.994 & 1.000 & 0.982 & 0.789 & 0.844 \\
\hline & B.S. & 0.002 & 0.000 & 0.918 & 0.003 & 0.000 & & 0.000 & 0.062 & 0.035 \\
\hline \multirow[t]{2}{*}{$I_{3616 \mathrm{~m}^{1}}$} & C.C. & 0.922 & -0.990 & 0.030 & -0.971 & 0.982 & 0.982 & 1.000 & 0.722 & 0.803 \\
\hline & B.S. & 0.009 & 0.000 & 0.955 & 0.001 & 0.000 & 0.000 & & 0.105 & 0.055 \\
\hline \multirow[t]{2}{*}{$I_{912} \mathrm{~m}^{\mathrm{r}}$} & C.C. & 0.918 & -0.744 & -0.647 & -0.75 & 0.722 & 0.789 & 0.722 & 1.000 & 0.966 \\
\hline & B.S. & 0.010 & 0.090 & 0.165 & 0.080 & 0.105 & 0.062 & 0.105 & & 0.002 \\
\hline \multirow[t]{2}{*}{$I_{510} \mathrm{~m}^{1}$} & C.C. & 0.924 & -0.797 & -0.490 & -0.787 & 0.788 & 0.844 & 0.803 & 0.966 & 1.000 \\
\hline & B.S. & 0.008 & 0.058 & 0.324 & 0.063 & 0.063 & 0.035 & 0.055 & 0.002 & \\
\hline
\end{tabular}

C.C.: correlation coefficients of Pearson. B.S.: bilateral signification. 


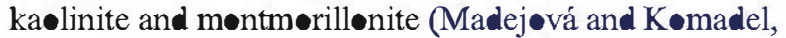
2001).

The second effect $\bullet$ bserved in this region in the samples studied is a peak or shoulder at $3580 \mathrm{~cm}^{1}$ (labelled as 2 in Fig. 3c). This peak is not present in the LIS sample, while in the TOR sample it appears with the highest intensity. Mendelovici (1973) found a peak at $3590 \mathrm{~cm}{ }^{1}$ which shifts to $3570 \mathrm{~cm}^{1}$ on heating, and Shuali et al. (1987) and Augsburger et al. (1998) assigned the weak band at $3580 \mathrm{~cm}{ }^{1}$ to coordinated water molecules in the channels. Serna et al. (1977) attributed this band to $\mathrm{Al}-\mathrm{Fe}^{3+}-\mathrm{OH}$ or $\mathrm{Al}-\mathrm{Mg}-\mathrm{OH}$ bønds, while Chahi et al. (2002), based on comparison with smectite, attributed it to $\mathrm{Al}-\mathrm{Fe}-\mathrm{OH}$ stretching. In the samples here studied there is a good correlation between the intensity of this peak and the Fe content. The LIS sample is the only sample that does not have $\mathrm{Fe}^{3+}(\mathbf{0 . 0 4})$, while the TOR sample is the one which presents the greatest content in $\mathrm{Fe}^{3+}$ of the samples studied (0.37). The YUC and ATT samples both present similar $\mathrm{Fe}^{3+}$ content $(\approx \mathbf{0} .24)$ and as can be observed in the spectra, they have similar intensity for the 3580 $\mathrm{cm}^{1}$ shoulder. In the ESQ and TRA samples the content is lower than in the other samples, $0.20 \%$ and
$0.16 \%$, respectively, and the abserption feature als• appears as a smaller shoulder. If the correlation with the $\mathrm{Fe}^{3+}$ content is taken inte account, the possibility that the $\mathrm{Fe}^{3+}$ is located in M2 position may be considered (Fig. 3b). This is in agreement with Delineau et al. (1994) in their study on the irøn content of ka linite and, with Bessen and Drits' (1997a,b) study of the relationships between chemical compesition of diectahedral mica minerals and their $\mathbf{R}$ spectra. They found that the wavenumber of the band corresponding to $\mathbf{O H}$ groups increased with the sum of the valences of the cations in $\mathrm{M}-\mathrm{M}-\mathrm{OH}$ bonds, but for the same sum of valences the increase of mass of the cations leads to a decrease in wavenumber of the corresponding band. Thus, in mica the $\mathrm{Al}-\mathrm{Al}-\mathrm{OH}$ stretching vibration appears at $3621 \mathrm{~cm}^{1}$ and that corresponding to $\mathrm{Al}-$ $\mathrm{Fe}^{3+}-\mathrm{OH}$ at $3573 \mathrm{~cm}^{1}$.

With respect to the three bands centred at 3550 , 3400 and $3350 \mathrm{~cm}{ }^{~}$, as can be seen in Fig. 3c, the samples studie are similar in position but not in intensity. There is geod agreement in the literature recording the assignation at water molecules (cøordinated and zelitic water), but according to Ausburger et al. (1998) "the band at $3543 \mathrm{~cm}^{1}$ is excessively strong
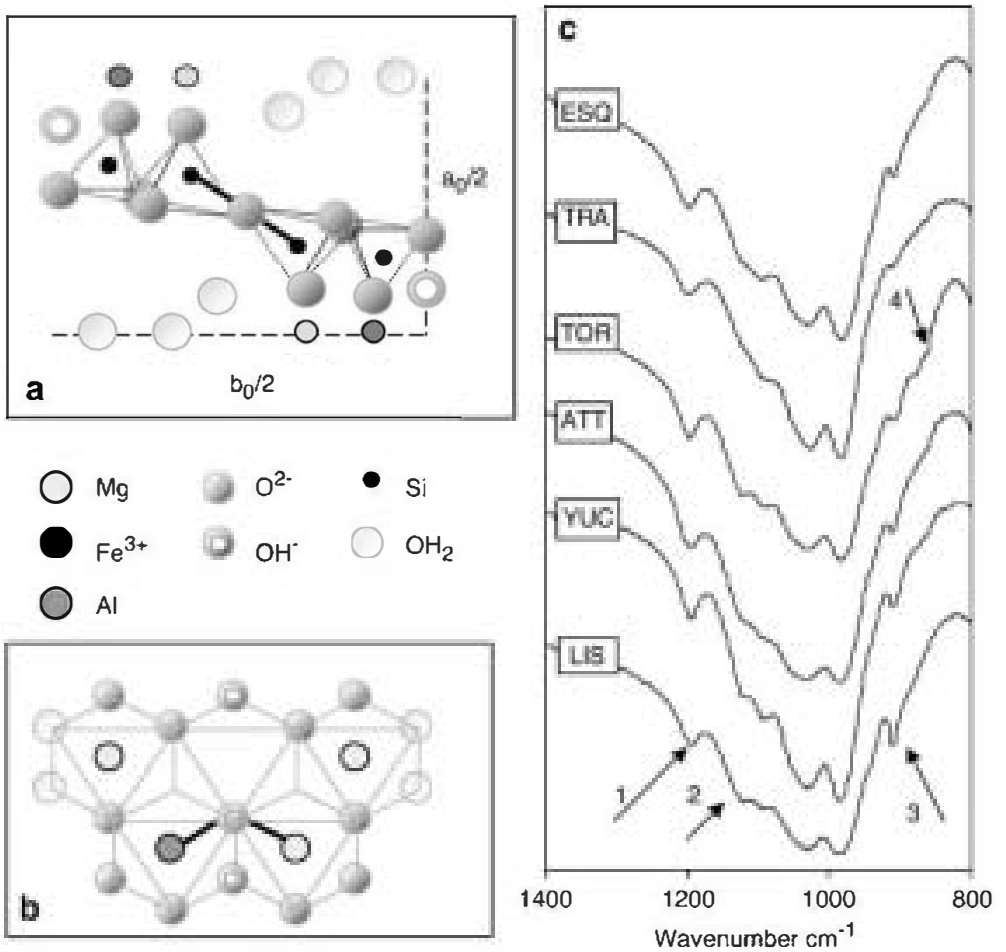

Fig. 4. (a) Structural scheme of bonds between altemative ribbons in palygorskite showing the Si-O-Si bond. (b) Structural scheme of octahedral sheet for a half-cell of palygorskite showing AI-Mg-OH bond. (c) FTIR spectra in the region between 800 and $1400 \mathrm{~cm}{ }^{1}$ of the palygorskites studied. 
and sharp to be assigned only to coordinated water; a contribution of the $\mathbf{O H}$-stretching mode in $\mathrm{Al}-\mathrm{Mg}-$ $\mathbf{O H}, \mathrm{Fe}-\mathrm{Mg}-\mathrm{OH}$ and $\mathrm{Fe}_{2}-\mathrm{H}$ groups is alse considered". The peak intensities •bserve in the samples studied seem to be in agreement with this observation because the richest in $\mathbf{M g}$ palygorskites present the lowest intensity due to the fact that they have the greatest triectahedral character.

It is important to note that, even in the richest in $\mathbf{M g}$ palygerskites (the ESQ and TRA samples), there is ne absørption at $3680 \mathrm{~cm}{ }^{1}$ which correspends to $3 \mathrm{Mg}-$ $\mathbf{O H}$, that it is to say, $\mathrm{Mg}$ in triectahedral coordination. According to Bessen and Drits (1997a,b) a possible $\mathrm{Mg}-\mathrm{Mg}-\mathrm{OH}$ bond must produce an abserption at higher wavenumber than $3616 \mathrm{~cm}^{1}$ (that correspends to $\mathrm{Al}-\mathrm{Al}-\mathrm{OH}$ ) because the sum of the valencies is lower. None of the samples now studied presents a peak at higher wavenumbers, and this means that there

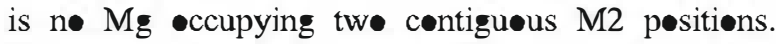
There are $\bullet$ ther references to Mg-rich palygorskites (Blance et al., 1989; Chahi et al., 2002; Cai and Xue, 2004) but in all cases they have triectahedral $\mathrm{Mg}$, and thus a peak at $3680 \mathrm{~cm}^{1}$ is found. In our samples, although the trioctahedral character is very high, the distribution of $\mathrm{Mg}, \mathrm{Al}$ and $\mathrm{Fe}$ must be withøut $3 \mathrm{Mg}-$ OH bønds, as propesed for the ESQ sample (GarcíaR•mer• et al., 2004).

\subsubsection{Water-bending vibration region}

An asymmetric band, centre at $1650 \mathrm{~cm}{ }^{1}$, appears in all samples studied. Mendelevici (1973) and Mende-

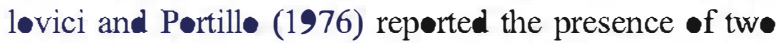
partially reselved peaks at 1655 and $1630 \mathrm{~cm}^{1}$. It is well known that this effect corresponds to bending modes of absørbed and zeolitic water.

In Figs. 4 and 5, the region of the lowest wavenumbers can be seen. Between 1200 and $400 \mathrm{~cm}{ }^{1}$ characteristic bands of silicate can be observed, mainly those corresponding to $\mathrm{Si}-\mathrm{b}$ bonds in the tetrahedral sheet, and alse to $\mathrm{M}-0$ stretching vibrational bonds. This interval of wavenumber is very complex because the lattice modes alsø have an influence in this region of the spectra. For this reasen there are few interpretations published abøut this region in palygorskite spectra. However, it is especially interesting because it provides information abøut the nature of the octahedral sheet.

Frest et al. (2001) assigned the abserption found between 1160 and $1115 \mathrm{~cm}^{1}$ to $\mathrm{Si}-$ stretching modes and those between 986 and $655 \mathrm{~cm}^{1}$ to $\mathrm{M}-$ OH deformation. When the spectra of the samples are compared, some important differences are found. The first peak that appears in this region in all samples

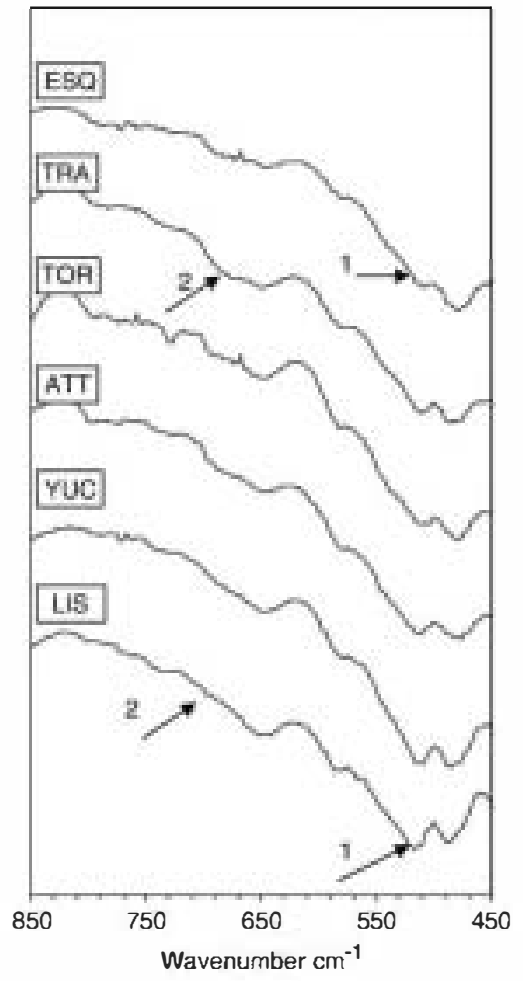

Fig. 5. FTIR spectra in the region between 450 and $900 \mathrm{~cm}^{1}$ of the palygorskites studied.

studied is lecated at $1190 \mathrm{~cm}^{1}$ (labelled as 1 in Fig. 4c). Mendelovici (1973) reported this peak as characteristic of palygorskite. It is important to note that it does not appear in $\bullet$ ther clay silicates, except in sepi-

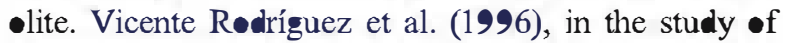
several phyllesilicates and their structural modifications during acid treatment by FTR, found the peak at $1190 \mathrm{~cm}{ }^{1}$ in sepielite and palygorskite, but n॰t in lamellar clay minerals. The structure of palygorskite and sepielite, with periødical inversion $\bullet$ apical $\bullet x y-$ gen in tetrahedra, presents an $\mathrm{Si}-\mathrm{O}-\mathrm{Si}$ bond between alternative ribbons (Fig. 4a). This bond is particularly noticeable in FTR spectra with the abserption at 1190 $\mathrm{cm}^{1}$ (Yariv, 1986).

At lower wavenumber there is a doublet placed at around $1100 \mathrm{~cm}^{1}$ (labelled as 2 in Fig. 4c) that may correspønd to $\mathrm{M}-0$ stretching vibrations (Blance et al., 1989) or Si- (Ausgburger et al. 1998; Frøst et al., 2001). The first peak, at $1084 \mathrm{~cm}{ }^{1}$, appears in all samples, with the best definition in the YUC sample (the most crystalline sample). The second peak, at 1116 $\mathrm{cm}{ }^{1}$, appears as a shøulder in the ESQ sample, and its intensity may be related to the diectahedral character.

The most intense peaks at 980 and $1024 \mathrm{~cm}^{1}$ are these corresponding to stretching of the $\mathrm{Si}-\mathrm{b}$ bond 
(Blance et al., 1989). In all samples studied, the pesition and intensity of both peaks are similar.

With respect to the peak that appears at $910 \mathrm{~cm}{ }^{1}$, as can be seen in Fig. 4c (labelled as 3), this sharp peak is present in all spectra but with different intensity, the most intense peak corresponds to the LIS sample. There is good coincidence in bibliegraphy with respect to the assignation of this peak (sometimes reported at $912 \mathrm{~cm}^{1}$ ). This peak corresponds to $\mathrm{Al}-$ $\mathrm{Al}-\mathrm{H}$ deformation, and it is a consequence of the dominantly diectahedral character of palygorskite (Madejøvá and Komadel, 2001). For Augsburger et a1. (1998) this band alse encleses the symmetric stretching mode $\mathbf{O}^{\prime}-\mathrm{Si}_{3}$. If the intensity of the peak (measure by difference of the intensity at $918 \mathrm{~cm}{ }^{1}$ ) is taken int account and is correlate with crystallochemical parameters, it will be noted $\left(I_{12} \mathrm{~cm}^{1}\right.$ in Table 2) that this peak is directly related to the $\mathrm{Al}$ content (cøefficient of correlation 0.918).

There is a small shoulder centred at $860 \mathrm{~cm}^{1}$ (Fig. $4 \mathrm{c}$, labelled as 4). This shoulder has been adscribed to the bending vibration mode of $\mathrm{Al}-\mathrm{Fe}-\mathrm{OH}$ bond (Fig. 3b), by Farmer (1974) for smectite and Chabi et al. (2002) for palygerskite. This assignation is in agreement with the intensity observed in the spectra of the samples studied, because the highest intensity correspønds to the TOR sample (labelled as 3 in Fig. 4c), the richest in $\mathrm{Fe} \bullet$ f the palygorskites studied. Madejøva and Komadel (2001) interpreted the shoulder at 860 $\mathrm{cm}^{1}$ as due to the $\mathrm{Al}-\mathbf{M g}-\mathrm{OH}$ bond, in which case the sample with the greatest intensity for this effect must be the ATT sample, the most dioctahedral sample with lowest $\mathrm{R}^{3+}$ value (Table 1 ), but this is not experimentally found.

For Farmer (॰p. cit.) and Chahi et al. (2002), the presence of $\mathrm{Al}-\mathrm{Mg}-\mathrm{H}$ bønds produces an abserption at $834 \mathrm{~cm}{ }^{1}$. This effect is not observed in the palygorskites here studied, neither in the most diectahedral ones (LIS, YUC and ATT samples). If the assignation at the $\mathrm{Al}-\mathrm{Mg}-\mathrm{H}$ bond is taken int account, this means that in these samples the $\mathbf{M g} \bullet$ ccupy the M2 p•sition. If -nly $\mathrm{Al}$ and $\mathrm{Fe}^{3+}$ eccupy $\mathrm{M} 2$ pesition, then there may be a percentage vacancies in this pesition for diectahedral samples, because $\mathrm{R}^{3+}$ ranges between 1.95 and 1.72 , but this does not seem possible. However, bearing in mind that there are $\mathbf{M g}$ in excess for M3 position, it is pessible to assume that this cation als $\bullet$ ccupies a small percentage of M2 pesition (as in Fig. 4b). The Mg content occupying the M2 position ranges between 1/ 10 and 1/7 per half-cell in the LIS and ATT samples respectively, but this is to॰ small to give a clear spectral respønse.
The interpretation of the løwest wavenumber regiøn, that corresponds to $450-700 \mathrm{~cm}{ }^{1}$, is very problematic because "this part of the spectrum is of complex $\bullet$ rigin, with contribution from $\mathrm{Si}-\mathbf{S}-\mathrm{Si}$ and $\mathbf{O}^{\prime}-\mathrm{Si}_{3}$ bending vibrations and lattice modes" (Augsburger et al., 1998). For this reasøn, and because the spectrometers have lower capacity of resolution in this region, there are very few references to this $\mathbf{R}$ region in palygorskite. More ver, this region is important because in the sequence of Si-O-M-O-Si bønds, a very impertant factor is the nature of $\mathrm{M}(\mathrm{Mg}, \mathrm{Al}, \mathrm{Fe} . .$.$) while the$ triectahedral or diectahedral surrounding has less influence. When the samples are compared (Fig. 5) it is possible to ebserve imp•rtant differences and similarities, which can be related to chemical compesition $\bullet$ the -ctahedral layer. There are three bands place at 480 , 578 and $647 \mathrm{~cm}^{1}$ that appear almost with the same intensity in all samples. It is possible to assume that they are not influenced by the ectahedral compesition and therefore, they are related to bonds corresponding to tetrahedral sheet. On the contrary, the bands that appear at $510 \mathrm{~cm}{ }^{1}$ and the shoulder at $676 \mathrm{~cm}^{1}$ (labelled as 1 and 2 in Fig. 5, respectively) vary in intensity for different palygorskites and thus permit, for the first time, the assignation of both bands. As with the 3616 and $\mathbf{9 1 2}$ $\mathrm{cm}{ }^{1}$ peaks, the intensity of the $510 \mathrm{~cm}^{1}$ peak was correlate with crystallechemical parameters and, as can be seen $\left(I_{51} \bullet \mathrm{cm}^{1}\right.$ in Table 2$)$, this peak is directly correlated with the $\mathrm{Al}$ ectahedral content (correlation coefficient $=0.924$ ) and by anal-gy with smectite, this band is probably due to Si-O-Al(IV). The shoulder at $676 \mathrm{~cm}{ }^{1}$ is related to the $\mathrm{Mg}$ content, and for Chahi et a1. (2002) this band is probably due to bending $\mathrm{Mg}_{3}-$ $O H$, but the effect due to the stretching mode of this bond does not appear in the samples here studied.

While it is observed that the lower is the content in $\mathrm{Al}$, the løwer is the intensity $\bullet$ the related FT R effects, the increase in the $\mathrm{Mg}$ content is not reflected as a parallel increase in the intensity of the effects invelving this element. Only the higher intensity in the shoulder at $670 \mathrm{~cm}{ }^{1}$ runs parallel to the increase if $\mathrm{Mg}$ content. On the contrary, the substitution in tetrahedral sheet is nøt easily detectable.

\section{Conclusions}

Several palygorskites with different chemical compesition have been studied: four diectahedral samples and tw with higher triectahedral character. Differences in composition of the •ctahedral sheet only seem to affect the M2 positions. All palygorskites here studied and these reported in bibliegraphy contain more than 2 
atoms of $\mathrm{Mg}$ per half-cell, therefore there is always enøugh $\mathrm{Mg}$ to complete M3 positions. Al •ccupies M2 positions in all samples studied, and if there is isømorphic substitution of $\mathrm{Al}$ by $\mathrm{Fe}$ this element alse -ccupies M2 pesitions. If the sum of $\mathrm{Al}^{\mathrm{VI}}$ and $\mathrm{Fe}^{3+}$ is less than 2 then $\mathrm{Mg}$ may alse eccupy this pesition. In the spectra, the vibrations corresponding to M3$\mathbf{O H}_{2}$ bonds are similar because there is always enough Mg to complete M3 position. Since the M2 position is that which reflects the chemical variations, $2 \mathrm{M} 2-\mathbf{O H}$ bonds have the greatest influence in spectra and reflect these differences. If several palygorskites are compared it is possible to identify those which present the highest $\mathrm{Al}$ content (most intense, 912 and $510 \mathrm{~cm}^{1}$ peaks), the highest $\mathrm{Fe}$ content $\left(3590 \mathrm{~cm}^{1}\right.$ and 880 $\mathrm{cm}^{1}$ shoulders), and the highest diøctahedral character (most intense $3616 \mathrm{~cm}^{1}$ peak).

The decrease of the intensity of the most characteristic peaks in the spectra of palygorskite is clearly related to the increase in $\mathrm{Mg}$ content. In the most

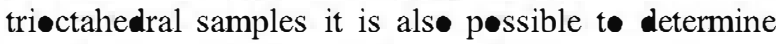

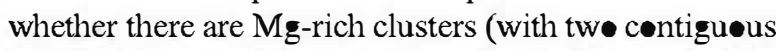
M2 positions, and the corresponding M1, occupied by $\mathrm{Mg}$ ) or whether the distribution of the "excess" of $\mathbf{M g}$ is aløng the ectahedral ribbøn, but withøut $3 \mathrm{Mg}-\mathbf{O H}$ triectahedral bonds. The tw• Mg-palygerskites here studie have ne triectahedral $\mathrm{Mg}$ bends because the $3680 \mathrm{~cm}{ }^{1}$ peak is not found.

\section{Acknowledgments}

We acknøwledge Dr. Güven and an anønymøus reviewer for their detailed revision to improve this work. We would like to express our gratitude to Dr. Silveri॰

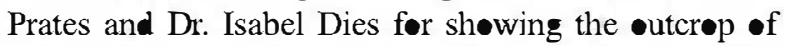
palygorskite from Lisbon (the LIS sample) and to Dr. Manuel Sanchez del Ri॰ and TOLSA company for supplying the YUC and TOR samples, respectively. We alsø express $\bullet$ ur sincere thanks to Dr. Raquel Trujillan for technical assistance, to Dr. Miguel Angel Vicente for his helpful comments and to Catherine Doyle for checking and improving the English style. Financial suppørt by CICYT (Prøject BTE2002-04017CO2) and Junta de Castilla y León (Project SA017A05) is als• acknøwledged.

\section{References}

Augsburger, M.S., Strasser, E., Perino, E., Mercader, R.C., Pedregosa, J.C., 1998. FTIR and Mössbauer investigation of a substituted palygorskite: silicate with a channel sucture. Journal of Physical Chemical Solids 59-2, 175-180
Besson, G., Drits, V.A., 1997a. Refined relationships between chemical composition of dioctahedral fine-grained micaceous minerals and theirinfrared spectra within the $\mathrm{OH}$ stretching region: Part II. Identification of the $\mathrm{OH}$ stretching bands. Clays and Clay Minerals 45-2, 158-169.

Besson, G., Drits, V.A., 1997b. Refined relationships between chemical composition of dioctahedral fine-grained micaceous minerals and theirinf rared spectra within the $\mathrm{OH}$ stretching region: Part I. The main factors affecting $\mathrm{OH}$ vibrations and quantitative analysis. Clays and Clay Minerals 45-2, 158-169.

Blanco, C., Herrero, J., Mendiroz, S., Pajares, J.A., 1988. Infrared studies of surface acidity and reversible folding in palygorskite. Clays and Clay Minerals 36-4, 364-368.

Blanco, C., González, F., Pesquera, C., Benito, I., 1989. Differences between one ahuninic palygorskite and another magnesic by infrared spectroscopy. Spectroscopy Letters 22, 659-673.

Bradley, W.F., 194. The structural scheme of attapulgite. American Mineralogist 25, 405-411.

Cai, Y.F., Xue, J.Y., 2004. Dissolution behaviour and dissolution mechanism of palygorskite in HCI solution. Progress in Natural Science 14 (3), 235-240.

Cases, R.A., Grillet, Y., François, M., Michot, L.F., Yvon, J., 1991. Evolution of the porous structure and surface area of palygorskite under vacuum thennal treatnent. Clays and Clay Minerals 39 (2), 191-201

Chahi, A., Petit, S., Decarreau, A., 2002. Infrared evidence of dioctahedral-rioctahedral site occupancy in palygorskite. Clays and Clay Minerals 50 (3), 306-313.

Costazo, P.M., Guggenheim, S. (Eds.), 2001. Baseline Studies of the Clay Minerals Society Source Clays. Clays Clay Miner., vol. 49 (5), pp. 371-453.

Delineau, T., Allart, T., Muller, J.P., Barres, O., Yvon, J., Cases, J.M., 1994. FTIR reflectance vs. EPR studies of structural iron in kaolinites. Clays and Clay Minerals 42, 308-320

Farner, V.C., 1974. The layer silicates. In: Farner, V.C. (Ed.), The Infared Spectra of Minerals. Monograph, vol. 4. Mineralogical Society, London, pp. 331-364.

Femández Macarro, B., Blanco Sánchez, J.A., 1990. The palygorskitecontaining Paleosols of the Talavan-Torrejon el Rubio Basin (Caceres, Spain); mineralogical and geochemical evolution. Chemical Geology 84 (1-4), 54-57.

Frost, R.L., Cash, G.A., Kloprogge, J.T., 1998. "Rocky Mountain leather", sepiolite and attapulgite - an infrared emission spectroscopic study. Vibrational Spectroscopy 16, 173-184.

Frost, R.L., Locos, O.B., Ruan, J., Kloprogge, J.T., 2001. Nearinfrared and mid-infrared spectroscopic study of sepiolites and palygorskites. Vibrational Spectroscopy 27, 1-3.

Galán, E., Brell, J.M., La Iglesia, A., Robertson, R.H.S., 1973. The Cáceres palygorskite deposit, Spain. Procc. Intem. Clay Conf., pp. $81-94$.

García-Romero, E., Suárez, M., Bustillo, M.A., 2004. Characteristics of a Mg-palygorskite in Miocene rocks (Madrid Basin, Spain). Clays and Clay Minerals 52 (4), 486-496.

Güven, N., Caillere, J.P.E., Fripiat, J.J., 1992. The coordination of ahuminum ions in the palygorskite stucture. Clays and Clay Minerals 4 (4), 457-461.

Hayashi, H., Otsuka, R., Inai, N., 1969. Infrared study of sepiolite and palygorskite on heating. American Mineralogist 53, 1613-1624.

Isphording, W.C., 1984. The clays of Yucatan, Mexico; a contrast in genesis. In: Singer, A., Galan, E. (Eds.), Palygorskite-sepiolite Occurrences, Genesis and Uses. Developments in Sedimentology, 37, pp. 59-73. 
Jones, B.F., Galán, E., 1988. Sepiolite and palygorskite. In: Bailey, S. W. (Ed.), Hydrous Phyllosilicates (exclusive of micas). Mineralogical Society of America, pp. 631-674.

Khorami, J., Lemieux, A., 1989. Comparison of attapulgites from different sources using TG/DTG and FTIR. Tennoquímica Acta 138, 97-105.

Madejová, J., Komadel, P., 2001. Baseline studies of the Clay Minerals Society source clays: infrare spectroscopy. Clays and Clay Minerals 49, 410-432.

Martín Vivaldi, J.L., Fenoll, P., 1970. Palygorskites and sepiolites (hornites). In: Mackenzie, R.C. (Ed.), Differential Thennal Analysis, vol. I. Academic Press, London, pp. 553-573.

McKeown, D.A., Post, J.E., Etz, E.S., 2002. Vibrational analysis of palygorskite and sepiolite. Clays and Clay Minerals 50-5, 667-680.

Mendelovici, E., 1973. Infrared study of attapulgite and HCI reated attapulgite. Clays and Clay Minerals 21, 115-119.

Mendelovici, E., Portillo, D., 1976. Organic derivatives of attapulgite: I. Infrared spectroscopy and X-ray diffraction studies. Clays and Clay Minerals 24, 177-182.
Prost, R., 1973. Spectre infrarouge de l'eau presente dans l'attapulgite et la sepiolite. Bulletin Française Argiles 53-63.

Sema, C., Van Scoyoc, G.E., Ahlrichs, J.L., 1977. Hydroxyl groups and water in palygorskite. American Mineralogist 62, 784-792.

Shuali, U., Steimberg, S., Yariv, M., Muller, M., Kahr, G., Rub, A., 1987. The adsorption of amines by sepiolite and palygorskite. Proc. Euroclay'87, Sevilla, pp. 502-503.

Singer, A., 1989. Palygorskite and sepiolite group minerals. In: Dixon, J.B., Weed, S.B. (Eds.), Mineral in Soil Environments. Soil. Sc. Soc. of Am., Madison, pp. 435-470.

Vicente Rodríguez, M.A., Suárez, M., Bañares, M.A., López González, J.D., 1996. Comparative FTIR study of the removal of octahedral cations and structural modifications during acid reament of several silicates. Spectrochimica Acta (A) 52, 1685-1694.

Yariv, S., 1986. Infrare evidence for the occurrence of $\mathrm{SiO}$ groups with double-bond character in antigorite, sepiolite and palygorskite. Clay Minerals 21 (5), 925-936. 